日顎変形誌 Jpn. J. Jaw Deform. 6 (2) : 162 169, October, 1996

\title{
顔面形態分類チャートによる顎顔面形態診断
}

$$
\begin{aligned}
& \text { 升井一朗 }{ }^{* 1} \text { 本田武司 }{ }^{* 1} \text { 宇治寿 隆 }{ }^{* 1} \\
& \text { 鴐 海美 帆 }{ }^{* 1} \text { 久保誼修*2 白数力也 }{ }^{* 2} \\
& \text { 吉田憲司 }{ }^{* 3} \text { 深谷昌彦*3 喜久田利弘 }{ }^{* 4} \\
& \text { 都温彦 }{ }^{* 4} \text { 古田治彦 }{ }^{* 5} \text { 福田仁一*5 }
\end{aligned}
$$

\section{Diagnosis of Maxillofacial Morphology by Facial Form Classification Chart}

\author{
ICHIRO MASUI ${ }^{*}$, TAKESHI HONDA ${ }^{* 1}$, TOSHITAKA UJI ${ }^{* 1}$, \\ MiHO OSHIUMI ${ }^{* 1}$, YoSHINOBU KUBO*2, RIKIYA SHIRASU*2 \\ KENJI YOSHIDA *3, MASAHIKO FUKAYA ${ }^{* 3}$, TOSHIHIRO KIKUTA *4, \\ HARUHIKo MIYAKO $* 4$, HARUHIKo FURUTA ${ }^{* 5}$ and JinICHI FUKUDA $* 5$
}

\begin{abstract}
In order to build a criterion of facial morphology diagnosis, the authors previously proposed the facial form classification chart. This chart was clinically used to diagnose 176 cases of maxillofacial deformity in five institutions, and these were subjected to a statistical study. The results were as follows :

1) Facial morphology diagnoses given to 176 cases aggregated 283 . The most common diagnosis was mandibular prognathism(123/176, 70\%), followed by facial asymmetry(66/176, 38.0\%), and maxillary retrognathism $(38 / 176,21.6 \%)$.

2) Ninety cases(90/176, 51.1\%) were given a single diagnosis and $86(86 / 176,48.9 \%)$ were given multiple diagnoses. Mandibular prognathism only was most common(56/176, 31.8\%), followed by mandibular prognathism with maxillary retrognathism $(33 / 176,18.8 \%)$, mandibular prognathism with facial asymmetry(29/176, 16.5\%), facial asymmetry single (19/176, 10.8\%) and so on.

3) The facial form classification chart was empirically assumed to systematize a common proress of facial morphology diagnosis, and offers a guide line that could standardize diagnosis of maxillofacial deformities.
\end{abstract}

$*_{1}$ 福岡歯科大学口腔外科学第 2 講座（主任：本田武司教授）

*2 大阪歯科大学口腔外科学第 1 講座（主任 : 白数力也教授）

*3 愛知学院大学歯学部口腔外科学第 1 講座 (主任 : 哚谷昌彦教授)

$*_{4}$ 福岡大学医学部歯科口腔外科学教室 (主任 : 都温彦教授)

*5 九州歯科大学口腔外科学第 1 講座 (主任: 福田仁一教授)

*1 Second Department of Oral and Maxillofacial Surgery, Fukuoka Dental College (Chief: Prof. Takeshi HONDA)

*2 First Department of Oral and Maxillofacial Surgery, Osaka Dental University (Chief: Prof. Rikiya SHIRASU)

*3 The 1st Department of Oral and Maxillofacial Surgery, School of Dentistry, Aichi-Gakuin University (Chief: Prof. Masahiko FUKAYA)

*4 Department of Oral and Maxillofacial Surgecy, School of Medicine, Fukuoka University (Chief: Prof. Haruhiko MIYAKO)

*5 First Department of Oral Surgery, Kyushu Dental College (Chiẹf: Prof. Jinichi FUKUDA) 
Key words : diagnosis (診断), maxillofacial deformity (頡顔面変形症), facial morphologic classification (顔面形態分類)

[Received Jul, 18, 1996]

\section{はじめに}

顎変形症は顎・顔面の変形と咬合の異常を主徵 とする症候群で，その診断名には顔面変形や不正 咬合の症候名がそのまま適用されることが多い。 不正咬合の診断は, 臼歯の咬合状態や前歯の被蓋 関係を Angle の分類や高橋の分類などの定義に 従って判定し, 該当する症候名が一義的に選択さ れる。一方, 顔面形態の診断は, 顔面全体の中で の相対的不調和を主観的に判断していると考えら れ，診断する者の主観に依存する部分が大きい。 また, 顔面形態の分類に統一性がないため, 類似 した症例でも診断者が変われば異なる診断名がつ けられることになり，術者間あるいは施設間での コミュニケイションの障害になっていると思われ る。

そこで私たちは，顎変形症の診断を基準化する ことを目的比，顔面変形の診査項目と手順拄よび 診断名を整理して, 顔面形態分類チャート試案を 作成し日本顎変形症学会誌 6 巻 1 号において発表 した ${ }^{1)}$ 。今回，著者らの所属する口腔外科 5 施設 を受診した顎変形症患者のうち, 顔面形態分類チ ヤートを適用した症例を対象に, 診断別症例数と 頻度, 診断と顔面形態所見との関係について検討 したので報告する。

\section{顔面形態分類チャートについて}

顔面形態分類チャート ${ }^{1}$ は，患者の正・側貌を 視診して, 側貌では上・中・下顔面の前後的突出 度を, 正貌では顔面の高さと対称性を診査して異 常所見を抽出し，12の診断名の中から該当するも のを選択するように作成されている。側貌の診査 は, 前頭骨部 (上顔面), 下眼瞼から鼻翼部, 鼻 背, 鼻下点から口唇接合部 (上唇部), 口唇接合 部からオトガイ唇溝部(下唇部), オトガイ唇溝部 からオトガイ部の 各部について， 们，普通， 凸）のいずれかを判断する。正貌の診査は顔面の 高さについて \{長顔傾向, 短顔傾向, 特になし\}
のいずれかを判定し, 対称性は 頭部非対称, 中 顔面非対称, 下顔面非対称, 中-下顔面非対称, 特になし）の中から選択する（Table 1)。なお， 各診查項目の判定と診断名の選択は, 診断者の主 観的判断に委礼ることとした。また， 1 症例に複 数の診断名が選択されることを許し，その順位を 問わないことにした。

\section{研究対象と方法}

1994年 1 月から1996年 3 月までの間に, 著者ら の所属する口腔外科 5 施設において顔面形態分類 チャートを適用し顎顔面形態診断を行った頡変形 症患者176名を対象とした。性別は男性41名, 女性

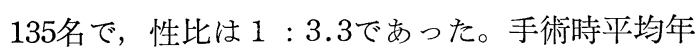
齢男性 22.8 歳, 女性23.8歳であった。

各施設で記入された顔面形態分類チャートを 1 施設に集め，データベースを構築して集計し，1） 顎顔面形態診断件数 (のべ数)，2）顎顔面形態診 断別症例数, 3) 顔面形態診查所見の集計,4）顎顔 面形態診断と側貌形態所見との関係について検討 した。

\section{結果}

\section{1. 顎顔面形態診断件数}

対象症例 176 例につけられた顎顔面形態診断名 は合計283件であった。診断名別にのべ数を集計 し，176例の中での頻度を求めた。その結果，下顎 前突症が 123 件で $70.0 \%$ を占め, 次に顔面非対称 66 件 $(38.0 \%)$, 上顎後退症38件 $(21.6 \%)$, 下顎歯 槽部前突症13件 (7.4\%), 下顎後退症および長顔 症が各11件 $(6.3 \%)$, その他の順であった（Table 2 )。

\section{2. 䫟顔面形態診断別症例数}

単独の診断名がついた症例は 90 例 (51.1\%), 複 数の診断名がついたものは86例 (48.9\%) でほぼ 同数であった。これらを症例数の多臭でみると， 下顎前突症単独が最多で56例 $(31.8 \%)$, 次に下顎 前突症 + 上顎後退症33例 $(18.8 \%)$, 下顎前突症 + 
Table 1 The facial form classification chart $^{1}$ )

1. Abnormality of facial profile

(1) Frontalis

(2) Lower eyelid to ala nasi

(3) Dorsum nasi

(4) Subnasale to stomion

(5) Stomion to sulcus mentolabialis

(6) Sulcus mentolabialis to menton

2. Front-facial form abnormality

1) Facial height abnormality

( ) 1. Tendency for long face

( ) 2. Tendency for short face

( ) 3. None

2) Facial asymmetry abnormality

( ) 1. Head asymmetry (occipital region, position of auricle, i. e. temple, and forehead, i. e. frontal region of head is asymmetrical)

( ) 2. Asymmetry of the middle part of face (diffrent position for pupils, curved dorsum nasi)

( ) 3. Asymmetry of the lower part of face (outline of face in the lower part of right and left tragus is asymmetrical.)

( ) 4. Asymmetry of middle and lower parts of face

( ) 5. None

$<$ Applied facial diagnosis $>$

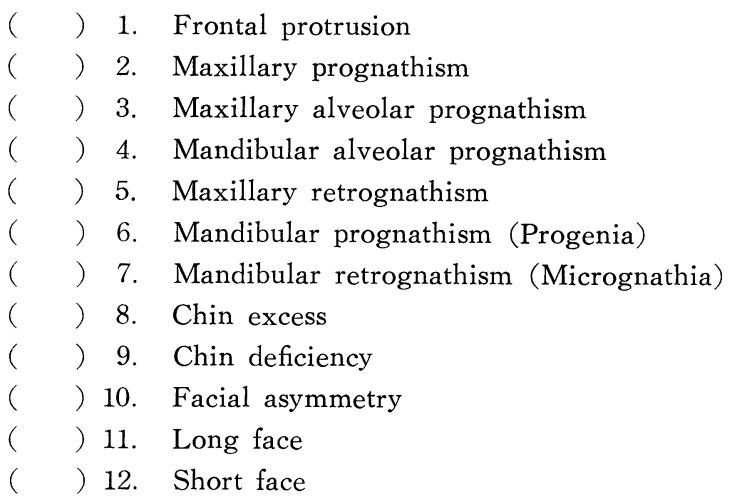

(slightly concave, normal, slightly convex) (slightly concave, normal, slightly convex) (slightly concave, normal, slightly convex) (slightly concave, normal, slightly convex) (slightly concave, normal, slightly convex) (slightly concave, normal, slightly convex)

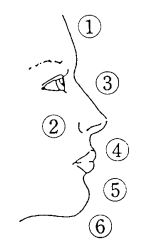

顔面非対称 29 例 (16.5\%), 顔面非対称単独 19 例 $(10.8 \%)$, 下顎後退症単独 7 例 $(4.0 \%)$, その他 の順であった。3つの診断名がついたものは18例 $(10.2 \%)$ で, その内 9 例 $(5.1 \%)$ は下顎前突症+ 上顎後退症に顔面非対称を合併した複雑な変形症 であった（Table 3)。
3. 顔面形態診查所見の集計
1）側貌所見 
Table 2 Diagnoses of maxillofacial morphology by 176 patients Number of cases indicates aggregate counts for each diagnosis.

\begin{tabular}{lcc}
\hline \multicolumn{1}{c}{ Diagnosis } & No. of cases & Frequency in 176 patients \\
\hline Frontal protrusion & 0 & $0.0 \%$ \\
Maxillary prognathism & 3 & 1.7 \\
Maxillary alveolar prognathism & 7 & 4.0 \\
Maxillary retrognathism & 38 & 21.6 \\
Mandibular prognathism & 123 & 70.0 \\
Mandibular alveolar prognathism & 13 & 7.4 \\
Mandibular retrognathism & 11 & 6.3 \\
Chin excess & 3 & 1.7 \\
Chin deficiency & 5 & 2.8 \\
Facial asymmetry & 66 & 38.0 \\
Long face & 11 & 6.3 \\
Short face & 3 & 1.7 \\
\hline
\end{tabular}

凹傾向にあるものと凸傾向にあるものはほぼ同数 で，前者は26例 $(14.8 \%)$, 後者は27例 $(15.3 \%)$ であった。口唇接合線からオトガイ唇溝(下唇部) は凸傾向を示すものが136例 $(77.3 \%)$ と圧倒的に 多く，四傾向を示すのはわずか 6 例 $(3.4 \%)$ であ った。オトガイ唇溝からオトガイ部では 109 例 (61.9\%) が凸傾向で, 凹傾向は14例 $(8.9 \%)$ と少 なかった（Table 4-1）。

\section{2) 正貌所見}

顔面の高さに不調和を認めたのは36例(20.5\%) で，長顔傾向が29例（16.5\%）に対して短顔傾向 は 7 例 $(4.0 \%)$ であった。

顔面の対称性では 104 例（59.1\%）が対称と判 定され，残り 4 割が非対称と判定された。非対称 の中では下顔面非対称が63例 (35.8\%) と最も多 $<$, 中・下顔面非対称 8 例 (7.4\%), 中顔面非対 称13例 $(4.5 \%)$, 頭部非対称 1 例 $(0.6 \%)$ の順で あった（Table 4-2)。

4. 顎顔面形態診断と側貌形態所見との関係

(1) 上顎の異常

上顎前突症，上頡歯槽部前突症，および上䫟後 退症の側貌形態所見を集計した。

上顎前突症は 3 例で, 下眼瞼から鼻翼部にかけ て 3 例とも凸傾向を示すが，鼻背および鼻下点か ら口唇接合線には必ずしも凸傾向はみられない。 上顎歯槽部前突症は 7 例で, 下眼瞼から鼻翼部は
凹傾向または普通で，上顎前突症と異なり凸傾向 は 1 例もなく, また鼻下点から口唇接合線は凸傾 向が 6 例にみられた。

上顎後退症は38例で, 下眼瞼から鼻翼部に凹傾 向を示すものが30例と多かった。鼻背では普通が 25例, 凹傾向は13例, 鼻下点から口唇接合線では 凹傾向が19例と最多であるが，普通10例，凹傾向 が 9 例と一定の傾向はみられなかった。したがっ て，上顎後退症と診断された症例の多くは下眼瞼 から鼻翼部に陥凹を認め, 鼻背は普通または陥凹 傾向がある。また，鼻下点から口唇接合線は半数 が陷凹しているが，他は普通または突出傾向を示 した (Table 5-1)。

(2) 下顎の異常

下顎前突症，下顎歯槽部前突症，および下顎後 退症の側貌形態所見を集計した。

下顎前突症は123例で, 口唇接合線からオトガイ 唇溝が凸傾向を示すもの117例, オトガイ唇溝から オトガイ部が凸傾向を示すものが108例であった。 下顎歯槽部前突症は13例で, 全例に口唇接合線か らオトガイ唇溝に凹傾向があるが, オトガイ唇溝 からオトガイ部にかけては普通または凹傾向であ った。下顎後退症は11例で，9例にオトガイ唇溝 からオトガイ部にかけて凹傾向を認めた（Table $5-2$ )。 
Table 3 Classification of 176 cases by the maxillofacial morphologic diagnosis

\begin{tabular}{|c|c|c|}
\hline Solitary Diagnosis & No. of cases & \\
\hline Mand. Prog. & $56(31.8 \%)$ & \\
\hline Mand. Retrog. & $7(4.0 \%)$ & \\
\hline Mand. Alv. Prog. & $3(1.7 \%)$ & \\
\hline Asymmetry & $19(10.8 \%)$ & \\
\hline Chin excess & $1(0.6 \%)$ & \\
\hline Chin deficiency & $1(0.6 \%)$ & \\
\hline Long face & $2(1.1 \%)$ & \\
\hline Short face & $1(0.6 \%)$ & \\
\hline Subtotal & $90(51.1 \%)$ & \\
\hline Plural diagnosis & No. of cases & Accompaning other diagnosis \\
\hline Mand. Prog. + Max. Retrog. & $33(18.8 \%)$ & $\begin{array}{l}\text { Asymmetry } 9, \text { Long face } 1 \\
\text { Short face } 1 \text {, Chin excess } 1\end{array}$ \\
\hline Mand. Prog. + Max. Alv. Prog. & $3(1.7 \%)$ & Asymmetry 1 \\
\hline Mand. Prog. + Asymmetry & $29(16.5 \%)$ & Long face 2 , Chin defic. 1 \\
\hline Mand. Prog. + Chin excess & $1(0.6 \%)$ & \\
\hline Mand. Prog. + Long face & $1(0.6 \%)$ & \\
\hline Mand. Alv. Prog. + Max. Prog. & $1(0.6 \%)$ & \\
\hline Mand. Alv. Prog. + Max. Alv. Prog. & $2(1.1 \%)$ & \\
\hline Mand. Alv. Prog. + Max. Retrog. & $2(1.1 \%)$ & \\
\hline Mand. Alv. Prog. + Chin deficiency & $1(0.6 \%)$ & \\
\hline Mand. Alv. Prog. + Asymmetry & $4(2.3 \%)$ & \\
\hline Mand. Retrog. + Max. Alv. Prog. & $2(1.1 \%)$ & Long face 1 \\
\hline Mand Retrog. + Max. Prog. & $2(1.1 \%)$ & Long face 1 \\
\hline Max. Retrog. + Long face & $2(1.1 \%)$ & \\
\hline Max. Retrog. + Asymmetry & $1(0.6 \%)$ & \\
\hline Chin deficiency + Asymmetry & $2(1.1 \%)$ & \\
\hline Subtotal & $86(48.9 \%)$ & \\
\hline Total & $176(100 \%)$ & \\
\hline
\end{tabular}

abbreviation

Mand. : Mandibular, Max. : Maxillary, Prog. : Prognathism, Retrog. : Retrognathism, Alv. : alveolar, Asymmetry : Facial asymmetry

\section{考察}

顔面形態の診断は, 患者の正貌・側貌を視診し て，顔面各部の角度や比率と顔面全体の中での調 和を認知して特徵抽出を行い，それを各診断者が イメージとして持っている顔面変形の症型と照合 して行われると考えられる。著者らの顔面形態分 類チャートは，正貌・側貌所見における特徴抽出 を一定の順序で行わせた後, 限られた診断名の中
から診断を選択させる方式で，各診査項目の判定 ならびに診断名の選択は主観的判断に任される。 したがって，本チャートは一般的な顔面形態の診 断過程をシステム化したものと言える。また，主 観的判断を残したことにより再現性に問題が残る が，顔面形態の評価に測定可能な評価法がない2) ため，診断者の主観に任されるべきものであると 考える。

対象症例の顎顔面形態診断を集計すると, 下顎 
Table 4-1 Result of profile view examination

\begin{tabular}{lccc}
\hline & Concave & Normal & Convex \\
\hline Frontalis & $12(6.8 \%)$ & $158(89.8 \%)$ & $6(3.4 \%)$ \\
\hline Lower eye lid to Ala nasi & $46(26.1 \%)$ & $126(71.6 \%)$ & $4(2.3 \%)$ \\
\hline Dorsum nasi & $18(10.2 \%)$ & $151(85.8 \%)$ & $7(4.0 \%)$ \\
\hline Subnasale to Stomion & $26(14.8 \%)$ & $123(70.0 \%)$ & $27(15.3 \%)$ \\
\hline Stomion to Sulcus mentolabialis & $6(3.4 \%)$ & $34(19.3 \%)$ & $136(77.3 \%)$ \\
\hline Sulcus mentolabialis to Menton & $14(8.0 \%)$ & $53(30.1 \%)$ & $109(61.9 \%)$ \\
\hline
\end{tabular}

Table 4-2 Result of full facial view examination

\begin{tabular}{|c|c|c|c|c|}
\hline \multirow[t]{2}{*}{1.} & Facial Height & Long face & Normal & Short face \\
\hline & & $29(16.5 \%)$ & $140(79.5 \%)$ & $7(4.0 \%)$ \\
\hline \multirow[t]{7}{*}{2.} & \multicolumn{4}{|c|}{ Facial Symmetry } \\
\hline & \multicolumn{2}{|l|}{ Symmetric } & \multicolumn{2}{|c|}{$104(59.1 \%)$} \\
\hline & \multicolumn{2}{|c|}{ Head Asymmetry } & \multicolumn{2}{|c|}{$1(0.6 \%)$} \\
\hline & \multicolumn{2}{|c|}{ Asymmetry of the middle face } & \multicolumn{2}{|c|}{$8(4.5 \%)$} \\
\hline & \multicolumn{2}{|c|}{ Asymmetry of the lower face } & \multicolumn{2}{|c|}{$63(35.8 \%)$} \\
\hline & \multicolumn{3}{|c|}{ Asymmetry of the middle and lower face } & $13(7.4 \%)$ \\
\hline & \multicolumn{2}{|c|}{ total } & \multicolumn{2}{|c|}{$176(100 \%)$} \\
\hline
\end{tabular}

Table 5-1 Relationship of profile view examination to resultant facial morphology diagnosis (anteroposterior aberation of the maxilla)

\begin{tabular}{l|ccc|ccc}
\hline \multirow{2}{*}{ Profile view examination } & \multicolumn{2}{|c|}{ Max. Prog. 3 cases } & \multicolumn{2}{c}{ Max. Alv. Prog. 7 cases } \\
\cline { 2 - 7 } & concave normal convex & concave & normal convex \\
\hline Frontalis & 1 & 2 & 0 & 2 & 5 & 0 \\
\hline Lower eye lid to Ala nasi & 0 & 0 & 3 & 2 & 5 & 0 \\
\hline Dorsum nasi & 0 & 2 & 1 & 2 & 4 & 1 \\
\hline Subnasale to Stomion & 0 & 1 & 2 & 0 & 1 & 6 \\
\hline
\end{tabular}

\begin{tabular}{l|ccc}
\hline \multirow{2}{*}{ Profile view examination } & \multicolumn{4}{c}{ Max. Retrog. 38 cases } \\
\cline { 2 - 4 } & concave & normal & convex \\
\hline Frontalis & 4 & 31 & 3 \\
\hline Lower eye lid to Ala nasi & 30 & 8 & 0 \\
\hline Dorsum nasi & 13 & 25 & 0 \\
\hline Subnasale to Stomion & 19 & 10 & 9 \\
\hline
\end{tabular}


Table 5-2 Relationship of profile view examination to resultant facial morphology diagnosis (anteroposterior aberation of the mandible)

\begin{tabular}{l|cccc|ccc}
\hline \multirow{2}{*}{ Profile view examination } & \multicolumn{2}{|c|}{ Mand. Prog. 123 cases } & \multicolumn{2}{c}{ Mand. Alv. Prog. 13 cases } \\
\cline { 2 - 7 } & concave & normal & convex & & concave & normal & convex \\
\hline Subnasale-Stomion & 21 & 84 & 18 & 0 & 8 & 5 \\
\hline Stomion-Sulcus mentolabialis & 1 & 5 & 117 & 0 & 0 & 13 \\
\hline Sulcus mentolabialis-Menton & 1 & 14 & 108 & 1 & 12 & 0 \\
\hline
\end{tabular}

\begin{tabular}{l|ccc}
\hline \multirow{2}{*}{ Profile view examination } & \multicolumn{4}{c}{ Mand. Retrog. 11 cases } \\
\cline { 2 - 4 } & concave & normal & convex \\
\hline Subnasale-Stomion & 1 & 6 & 4 \\
\hline Stomion-Sulcus mentolabialis & 5 & 5 & 1 \\
\hline Sulcus mentolabialis-Menton & 9 & 2 & 0 \\
\hline
\end{tabular}

前突症は70\%で，諸家の臨床統計報告と比較する と少ない。坪井ら ${ }^{3)}$ は 50 例中 49 例 $(98.0 \%)$ ， 久 保ら ${ }^{4)}$ は98例中92例 $(93.9 \%)$ ，冨田ら ${ }^{5)}$ は106例 中98例 $(92 \%)$, 迫田 $5^{6)}$ は76例中53例 $(69.7 \%)$, 和久田ら ${ }^{7)} 284$ 例中 263 例 $(92.6 \%)$ ，高橋ら ${ }^{8)}$ は $84 \%$, 山田ら ${ }^{91}$ は $88.8 \%$, 武藤ら ${ }^{10)}$ は223名中 191 例（86\%）が下顎前突症であったと報告している。 本チャートの集計で，下嚆前突症と上頡後退症 (21.6\%)を合わせると $91.6 \%$ となり，諸家の報告 の下顎前突症の割合とほぼ一致する。したがって 過去の報告では，上顎後退症も咬合状態の診断か ら一義的に下顎前突症に分類されたと考えられる。

上顎後退症と下顎前突症について側貌形態所見 を比較すると, 上顎後退症の多くは下眼瞼から鼻 翼部に陷凹を認め，鼻背は普通または凹傾向があ る。また, 鼻下点から口唇接合線 (上唇) は半数 が凹傾向であるが，他は普通または凹傾向を示す と考えられる。下顎前突症では，鼻下点から口唇 接合線は普通84例, 凹傾向21例, 凸傾向18例で上 唇にはバリエイションがあるが，口唇接合線から オトガイ唇溝 (下唇), およびオトガイ唇溝からオ トガイ部は凸傾向が圧倒的に多く, 下顎前突症の 診断にはオトガイ部の前突度が基準になると考え られる。

以上のように，本チャートを用いて顔面形態診 断を行うことは，主観的に行われる形態の認知と
診断名の選択に指針を与えることにもなり，顔面 形態診断の再現性に結びっくものと思われる。

\section{結 語}

口腔外科 5 施設を受診した顎変形症患者 176 名 に顔面形態分類チャート ${ }^{1}$ を適用し， 診断別症例 数と頻度, 診断と顔面形態所見との関係について 検討した。その結果, 以下の結論を得た。

1）本チャートは一般的な顔面形態の診断過程 をシステム化したものと言える。

2）従来下顎前突症に分類されていた症例の中 には上顎後退症が含まれていると思われる。

3）本チャートの使用は, 主観的な顔面形態の認 知と診断名の選択に指針を与えることになり，診 断の基準化に結びつくと考えられる。

今後は施設数をさらに増やして, 顎・顔面変形 症の臨床統計的調査を試みたいと考えている。

\section{文献}

1）久保誼修, 他 : 顎顔面変形症の顔面形態評価の試み. 日顎変形誌, $6: 76-82,1996$.

2) H. L. Obwegeser : 䅡変形症のための記述的用語. 日顎変形誌， $5: 125-129 ， 1995$.

3）坪井研吾，他：当科における頻矯正手術例の臨床的 検討. 日口外誌, $32: 2108-2119,1986$.

4）久保誼修，他：大阪歯科大学第 1 口腔外科における 顎矯正手術の臨床統計的観察. 日口診誌，2:128137, 1989.

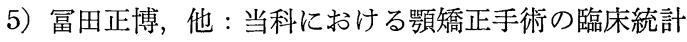


的検討. 口科誌, $40: 815-825,1991$.

6）迫田隅男, 他: 当科の顎矯正手術に関する臨床的検 討. 日顎変形誌，2：125-131，1992.

7）和久田哲生, 他：当院における外科的矯正治療の臨 床統計的観察. 日顎変形誌，4:177-183，1994.

8）高橋一郎, 他: 大阪歯科大学付属病院における頢変 形症患者の臨床統計的観察. 日顎変形誌, 5:184-
189, 1995.

9）山田 潔, 他 : 神戸大学口腔外科における顎矯正手 術施行例の臨床統計的観察. 日顎変形誌，6:105114, 1996.

10）武藤祐一，他：最近 10 年間に施行した 顎矯正手術 223名 (231例) の臨床統計的検討. 日顎変形誌, 6 : 115-121, 1996. 